\title{
Importance of consumers on exposed and sheltered rocky shores
}

\author{
N. E. O'Connor ${ }^{1,2, *}$, I. Donohue ${ }^{3}$, T. P. Crowe ${ }^{4}$, M. C. Emmerson ${ }^{1,2,5}$ \\ ${ }^{1}$ Environmental Research Institute, University College Cork, Lee Road, Cork, Ireland \\ ${ }^{2}$ School of Biological Sciences, Queen's University Belfast, 97 Lisburn Road, Belfast BT9 7BL, UK \\ ${ }^{3}$ School of Natural Sciences, Department of Zoology, Trinity College Dublin, Dublin 2, Ireland \\ ${ }^{4}$ School of Biology and Environmental Science, University College Dublin, Belfield, Dublin 4, Ireland \\ ${ }^{5}$ School of Biology, Earth and Environmental Sciences, University College Cork, North Mall, Cork, Ireland
}

\begin{abstract}
It is often suggested that the relative importance of biotic processes, such as recruitment, competition and predation of marine benthic species, varies predictably along a gradient of exposure to wave action. Several established models of community dynamics on rocky shores predict that top-down processes are more important for structuring communities on sheltered than on exposed shores. To test the relative dominance of top-down processes, we first measured the establishment of key benthic species (mussels, barnacles and algae) on 3 sheltered and 3 exposed rocky shores in southwest Ireland over two 6 mo periods. We then manipulated the presence of consumers (e.g. grazing gastropods, crabs, whelks), using caged exclosures, on 2 sheltered and 2 exposed shores to test for an interaction between effects of consumers and shore exposure on the establishment of benthic species. In contrast to predictions, we found that consumers strongly affected establishment of all species regardless of shore exposure. We also found that shore exposure was not a reliable predictor for spatial and temporal variation in rates of establishment of sessile benthic species. Our findings provide experimental evidence which demonstrates the importance of consumers in early post-settlement stages of benthic species-essential for the development of benthic-pelagic models.
\end{abstract}

KEY WORDS: Algae · Barnacles · Consumers · Grazers · Mussels · Intertidal · Rocky shore Resale or republication not permitted without written consent of the publisher

\section{INTRODUCTION}

The extent to which physical factors interact with dominant ecological processes varies in space and time across a range of scales, and a better understanding of this is crucial to our understanding of community dynamics (Menge 2000, Menge \& Branch 2001, Thompson et al. 2004). Several authors have argued for a more mechanistic understanding of consumer-driven top-down effects derived from experimental research across environmental gradients (Underwood \& Petraitis 1993, Maron \& Crone 2006, Daleo \& Iribarne 2009, Taylor \& Schiel 2010).
On rocky shores, a key challenge is to clarify the roles of direct physical effects, such as water movement, and biological effects, such as grazing and predation (Jonsson et al. 2006, Burrows et al. 2008).

Many rocky-shore community regulation models predict that environmental gradients in nutrients, physical harshness and disturbance can have major effects on the types and strengths of interactions among species (Connell 1975, Menge \& Sutherland 1976, 1987, Lubchenco 1983, Menge \& Olson 1990, Bruno et al. 2003). Several models predict that at low/mid-shore on wave-exposed shores, resource abundances are controlled by competition for space 
and physical disturbance, whereas on wave-sheltered shores resource abundance is more likely determined by predation and grazing (Menge \& Sutherland 1987, Menge \& Olson 1990, Menge \& Branch 2001). This is largely because wave action is presumed to affect the activity of mobile predators. However, separating the effects of large-scale physical processes on communities from those occurring at smaller spatial scales is challenging (Schiel 2004). Further, wave action is also predicted to affect bottom-up processes (Menge \& Olson 1990, Menge 1992), such as the settlement of micro-organisms from plankton, leading to macrobiotic production through post-settlement processes, such as recruitment and succession (Thompson et al. 2004). The effect of water movement on food supply for filter feeders has been considered analogous to the effects of nutrient supply to macroalgae and is treated as a bottom-up process in some models (Menge 1992). Abiotic factors can, however, affect all trophic levels, and water movement may modify communities 'laterally' rather than simply from the top or bottom of trophic cascades (Thompson et al. 2004).

Many studies have shown that the effects of consumers vary among rocky shores and can vary in both space and time (Petraitis 1990, Fairweather \& Underwood 1991, Menge et al. 1994, Rilov \& Schiel 2006, Sams \& Keough 2007). For example, Dayton (1971) excluded predators and grazers on exposed and sheltered shores on the west coast of North America and found contrasting results with comparable studies on the east coast of North America (e.g. Menge \& Sutherland 1976). In addition, several alternative models of the effects of grazers on rocky shores have been tested in Australia (e.g. Underwood 1981, Underwood \& Jernakoff 1981, 1984) and in Europe, where algae on sheltered shores are not always controlled by grazers (Hawkins \& Hartnoll 1983, Jenkins et al. 1999), in particular on more southern shores where variation in algal recruitment is thought be a determining factor (Hawkins et al. 1992, Coleman et al. 2006).

On rocky shores, predators consume benthic filter feeders directly, while grazing gastropods can have multiple effects; by 'bulldozing' juvenile filter feeders (Dayton 1971, Denley \& Underwood 1979, Hawkins 1983), as well as controlling algal abundance (Southward 1964, Underwood 1980, Hawkins \& Hartnoll 1983, Lubchenco 1983, Jenkins et al. 2001b). Grazers may inhibit barnacle recruitment directly by consumption (e.g. Dayton 1971, Denley \& Underwood 1979, Petraitis 1987) or enhance their recruitment by removing algal competitors (Under- wood et al. 1983, Jernakoff 1985, Benedetti-Cecchi 2000). In addition, grazers can slow or hasten the rate of succession depending upon whether they affect early or late successional species (Farrell 1991, Sousa \& Connell 1992) or cause a shift in the structure of the whole assemblage (Anderson \& Underwood 1997). It is, therefore, useful to consider the combined effects of both predators and grazers (consumers) on other benthic species, such as filter feeders and algae, to examine the importance of top-down effects. In addition, there is often a significant gap in time between settlement and recruitment to populations and the stages on which predation experiments are done, thereby altering our perception of how different oceanographic regimes affect top-down interactions (Schiel 2004).

We tested whether the establishment of benthic species differed between exposed and sheltered shores by quantifying mussel, barnacle and algal establishment over 2 consecutive 6 mo periods at 3 exposed and 3 sheltered rocky shores in southwest Ireland. We then examined experimentally whether the presence of consumers affected the establishment of benthic species and tested for an interaction with shore exposure by manipulating the presence of consumers at 2 exposed and 2 sheltered shores during the expected peak recruitment and growth period for $8 \mathrm{mo}$. We tested the following models: (1) establishment of benthic species is greater on exposed than sheltered shores, (2) consumers affect benthic species establishment on exposed and sheltered shores, and (3) effects of consumers on establishment of benthic species interact with shore exposure (i.e. consumers have a greater effect on sheltered than exposed shores).

\section{MATERIALS AND METHODS}

\section{Experimental design}

The present study was carried out on musseldominated rocky shores in County Cork, southwest Ireland. Three sheltered shores and 3 exposed shores were selected randomly to represent extremes of the exposure scale in this region. Sites were selected from a shortlist of 6 exposed and 6 sheltered shores based on exposure to wave activity of the open coasts deduced from field observations and maps $\left(\mathrm{O}^{\prime} \mathrm{Con}-\right.$ nor 2010). To quantify the level of shore exposure objectively, we also used a GIS-based wave exposure model (Scottish Association for Marine Science 2007) to estimate mean wave fetch $(F)$ at each site (Burrows 
et al. 2008). The exposed shores were close to Barley Cove $\left(51.466^{\circ} \mathrm{N}, 9.787^{\circ} \mathrm{W} ; F=5.34 \mathrm{~km}\right)$, Dunworley $\left(51.583^{\circ} \mathrm{N}, 9.752^{\circ} \mathrm{W} ; F=4.0 \mathrm{~km}\right)$ and Garrettstown $\left(51.643^{\circ} \mathrm{N}, 8.585^{\circ} \mathrm{W} ; F=3.89 \mathrm{~km}\right)$ and the sheltered shores were at Ringaskiddy $\left(51.832^{\circ} \mathrm{N}, 8.3^{\circ} \mathrm{W} ; F=\right.$ $0.08 \mathrm{~km})$, Roberts Cove $\left(51.744^{\circ} \mathrm{N}, 8.312^{\circ} \mathrm{W} ; F=\right.$ $0.92 \mathrm{~km})$ and Cusheen $\left(51.527^{\circ} \mathrm{N}, 9.5267^{\circ} \mathrm{W} ; F=\right.$ $0.26 \mathrm{~km})$ (Fig. 1). The mean wave fetch $( \pm \mathrm{SE})$ at exposed shores was $4.41 \pm 0.5 \mathrm{~km}$ ), which was significantly greater than $0.42 \pm 0.3 \mathrm{~km}$ ) at sheltered shores $\left(F_{1,4}=56.37, \mathrm{p}<0.002\right)$. At all locations the low/mid-shore comprised a mosaic of patches of mussels, macro-algal stands, barnacle-covered rock and 'bare' rock. The mussels were a mixture of Mytilus edulis, Mytilus galloprovincialis and hybrids between these 2 species (Coghlan \& Gosling 2007). For the purpose of the present study all mussels were considered Mytilus spp. Individual mussels on the sheltered shores were larger, had greater survival rates, and formed less dense patches than those on exposed shores, yet total mussel biomass within patches was similar on all shores (O'Connor 2010). Several barnacle species occur on these shores: Chthamalus stellatus was dominant on the exposed shores and Chthamalus montagui was dominant on sheltered shores (Delany et al. 2003, Power et al. 2006, O'Connor pers. obs.). Typical of rocky shores in the region (e.g. O'Connor et al. 2006, O'Connor \& Crowe 2008), the most common macroalgal species growing on rock and epibiotically on mussels were Ulva spp., Fucus serratus and Porphyra spp. on the exposed shores and Ulva spp., Fucus spiralis and Ascophyllum nodosum on the sheltered shores. The mean densities $( \pm \mathrm{SE})$ of grazing gastropods per $\mathrm{m}^{2}$ on emergent rock at low/mid-shore on the exposed shores comprised: $13 \pm 4$ ) patellids, $3 \pm 1$ ) littorinids and $6 \pm 2$ trochids; and on the sheltered shores $19 \pm 6$ ) patellids, $10 \pm 1$ littorinids and $7 \pm 2$ trochids, $\mathrm{n}=35$ (quadrats on each shore).

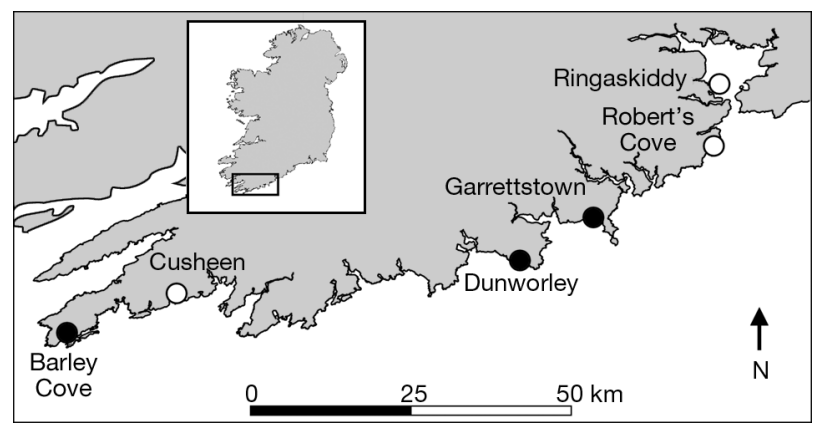

Fig. 1. Map of the southwest coast of Ireland, showing the exposed (closed circles) and sheltered (open circles) rocky shores examined in the present study
For sessile species with a pelagic larval/propagule phase, recruitment is generally defined as the process by which individuals become permanently attached and metamorphosed, and survive in an area for a specified period of time (Connell 1985, Minchinton \& Scheibling 1993). In the context of our study, we measured the establishment of benthic species, incorporating the period from recruitment to early growth of the adult form. Initially, to test whether benthic species establishment differed between exposed and sheltered shores, we measured the establishment of mussels (abundance), barnacles (abundance) and algae (biomass) on the 3 exposed and 3 sheltered shores over two 6 mo periods: March to August 2006 (Time 1) and September 2006 to February 2007 (Time 2). Subsequently, we examined experimentally the effects of consumers on benthic species establishment on 2 of the exposed and 2 of the sheltered shores over an 8 mo period from February to September 2007 (Time 3) that included peak expected recruitment periods (Hawkins 1981, King et al. 1989, Power et al. 2006).

First, 4 experimental plots $(35 \times 35 \mathrm{~cm})$ were established within intact areas of the mussel zone on each of the 6 shores (24 experimental units, $\mathrm{n}=4$ ). Plots were set up among mussels, and each plot was at least $1 \mathrm{~m}$ from the next. All plots were chosen to be representative of the shore and to include approximately similar assemblages. Thus, initially, each plot contained approximately 50\% mussel cover and up to $50 \%$ barnacle-covered rock. There were no macroalgal fronds attached inside the plots. To estimate mussel establishment, we attached plastic mesh pot scouring pads (Killeen), similar to those used in previous studies (e.g. King et al. 1990), in each experimental plot on each shore. At the end of each time period, pads were collected, frozen and stored for later analyses. The centre $25 \mathrm{~cm}^{2}$ of each pad was used for analyses to avoid fringe effects of proximity to the steel fixings. To count the mussels, pads were suspended in $10 \%$ bleach solution for 4 min to dissolve byssal threads and the number of individuals extracted was recorded. Mussels were also measured (maximum length, to the nearest $200 \mu \mathrm{m}$ ), and, although some mussels $(<10 \%)$ were $<400 \mu \mathrm{m}$ and could be considered newly settled mussels, and a very small number of mussels $(<2 \%)$ were $>5 \mathrm{~mm}$, for the purpose of the present study all mussels (mean length $[ \pm \mathrm{SE}]$ : $2.8 \pm 0.05 \mathrm{~mm}$ ) were considered recently established and grouped together for analyses. It is not possible to determine the source of mussel cohorts $>400 \mu \mathrm{m}$, which may include migrants or recruits (King et al. 
1990); however, we can estimate the establishment of mussel populations (incorporating some recruitment and early growth). To estimate barnacle establishment, we attached stone tiles $\left(100 \mathrm{~cm}^{2}\right)$ similar to those used in previous studies (e.g. Watson \& Barnes 2004) to the shore in each experimental plot. Tiles were retrieved at the end of each 6 mo time period, and all barnacles were identified and counted. All barnacles recorded were considered adults (mean length $[ \pm \mathrm{SE}]: 6.87 \pm 0.29 \mathrm{~mm}$ ). Additional stone tiles $\left(100 \mathrm{~cm}^{2}\right)$ were also attached within each plot to estimate algal establishment. These tiles were recovered at the end of each time period, and all algae were identified, removed from the tiles with a blade, oven dried $\left(65^{\circ} \mathrm{C}\right.$ for $\left.48 \mathrm{~h}\right)$ and their total biomass (dry weight) quantified.

Second, to test whether the presence of consumers affected establishment of benthic species and to test specifically for an interaction between consumer presence and level of shore exposure, the presence of consumers (e.g. fish, crabs, whelks and gastropod grazers) was manipulated at 2 exposed shores (Barley Cove and Dunworley) and 2 sheltered shores (Robert's Cove and Cusheen) during the final experimental period (Time 3). The use of cages to exclude consumers was unavoidable and care was taken to include suitable experimental controls (Underwood 1997, Quinn \& Keough 2002). Cages to exclude consumers consisted of square fences measuring 35 (length) $\times 35$ (width) $\times 12$ (height) $\mathrm{cm}$ and had roofs attached with cable ties, made of stainless steel mesh $(0.9 \mathrm{~mm}$ diameter, $3.33 \mathrm{~mm}$ aperture, $61 \%$ open area). Owing to the size of the mesh, it is possible that some small species (e.g. juvenile gastropod grazers, pea crabs Pinnotheres pisum, and meso-grazers such as amphipods and isopods) could access the plots, but the effects of these species were not included in the present study. Experimental plots that consumers had access to were marked with 2 stainless steel washers placed at opposite corners. Partial cages were erected to control for any effects of full cages. These were made from similar stainless steel mesh and were triangular fences with roofs at opposing corners of the square plot area. The interior of the partial cage was accessible to consumers, and $50 \%$ of the area of the plot was roofed. All experimental plots were marked out and numbered prior to the random allocation of treatments. All experimental plots were on a horizontal incline with relatively flat substrate to reduce any variances in grazing efficiency caused by heterogeneous substrate rugosity or slope (BenedettiCecchi et al. 2001). Each experimental plot con- tained 1 mussel collection pad, 1 barnacle collection plate and 1 algal collection plate. The establishment of mussels (abundance), barnacles (abundance) and total algae (biomass) was measured using similar methods to those described previously. The surface within each experimental plot remained intact (was not scrubbed), and the use of collection plates permitted sampling of newly established individuals. There were 4 replicate plots for each of 3 treatments: 'no consumers' (full cages), 'consumers' (no cages) and 'cage control' (partial cages) at each of the 4 shores (48 experimental units each for mussels, barnacles and algae). All plots were checked regularly (every 2 wk in the earlier months and at least every month thereafter) throughout the experiment so that treatments were maintained (i.e. no consumers could access the full cages, all structures were intact, algal (or other) biofouling was removed from cages if necessary and juvenile or small consumers that could settle inside the cages were removed).

\section{Data analyses}

We tested for differences in newly-established mussel and barnacle abundance and algal biomass on exposed and sheltered shores over the first 2 sampling periods with permutational ANOVA (PERMANOVA) (Anderson 2001, McArdle \& Anderson 2001, Anderson et al. 2008). The factors in these analyses were: Time (random, 2 levels), Exposure (fixed, 2 levels) and Location (random and nested in Exposure, 3 levels). Time was treated as a random factor because we were testing for differences in temporal variation and were not interested in those exact sampling periods that were selected arbitrarily (Underwood 1997). Exposure was treated as a fixed factor because we were concerned with the specific identifiable properties of each level of this factor (similar to experimental treatments). Location was treated as a random factor because all locations were selected to be representative of any exposed or sheltered rocky shore in the region and our models do not relate to the specific shores used in the study. Moreover, Location must be nested within the factor Exposure because each representative shore could only ever be exposed or sheltered, but not both. This nested or hierarchical (not orthogonal) design is essential to ensure appropriate and unconfounded replication (Underwood 1997). We used PERMANOVA rather than conventional ANOVA or a general linear mixed model to analyse these data 
with the PERMANOVA+ add-in to PRIMER (v. 6.1.10; PRIMER-E Ltd.) because these analyses required linear combinations of mean squares, given that they had 2 random factors in a multi-factorial nested design, which cannot be done using other more conventional analytical frameworks (Quinn \& Keough 2002). PERMANOVA provides p-values from permutations rather than by approximating them from tables, and our analyses were based on a Euclidian distance matrix with 9999 permutations of the residuals under a reduced model (Anderson et al. 2008). Prior to analyses, the distribution of each variable was examined for departures from normality and homoscedasticity and all data were $\log (x+1)$ transformed to achieve approximate unimodal symmetry. Pairwise post hoc tests with 9999 permutations were used to make comparisons among significant terms.

ANOVA was used to test for effects of consumers on mussel and barnacle abundance and algal biomass and to test for an interaction with shore exposure. These analyses incorporated 3 factors: Exposure (fixed, 2 levels), Location (random and nested in Exposure, 2 levels) and Treatment (fixed, 3 levels: full cage, no cage and cage control). Separate analyses were done for each of the groups: mussels, barnacles and algae. This experimental design differs from the former and contains only 1 random factor; thus, conventional ANOVA was possible. Cochran's test for homogeneity of variance was used prior to analyses, and data were transformed when necessary. Data were analysed when homogeneity of variances could not be achieved, because the ANOVA is robust for departure from this assumption when there are many independent replicates and sizes of samples are equal (Underwood 1997). These results (barnacle and algal biomass) were, however, interpreted with caution by judging the significance more conservatively ( $\alpha=0.01$ ). The Student-Newman-Keuls (SNK) procedure was used to make post hoc comparisons among significant terms.

\section{RESULTS}

\section{Effects of shore exposure on benthic species establishment}

The abundance of newly-established mussels was not affected by shore exposure but it varied among locations during the first sampling period (Time 1) (Fig. 2A, Table 1). At Time 1, mussel abundance at 2 of the exposed shores was greater than that at all
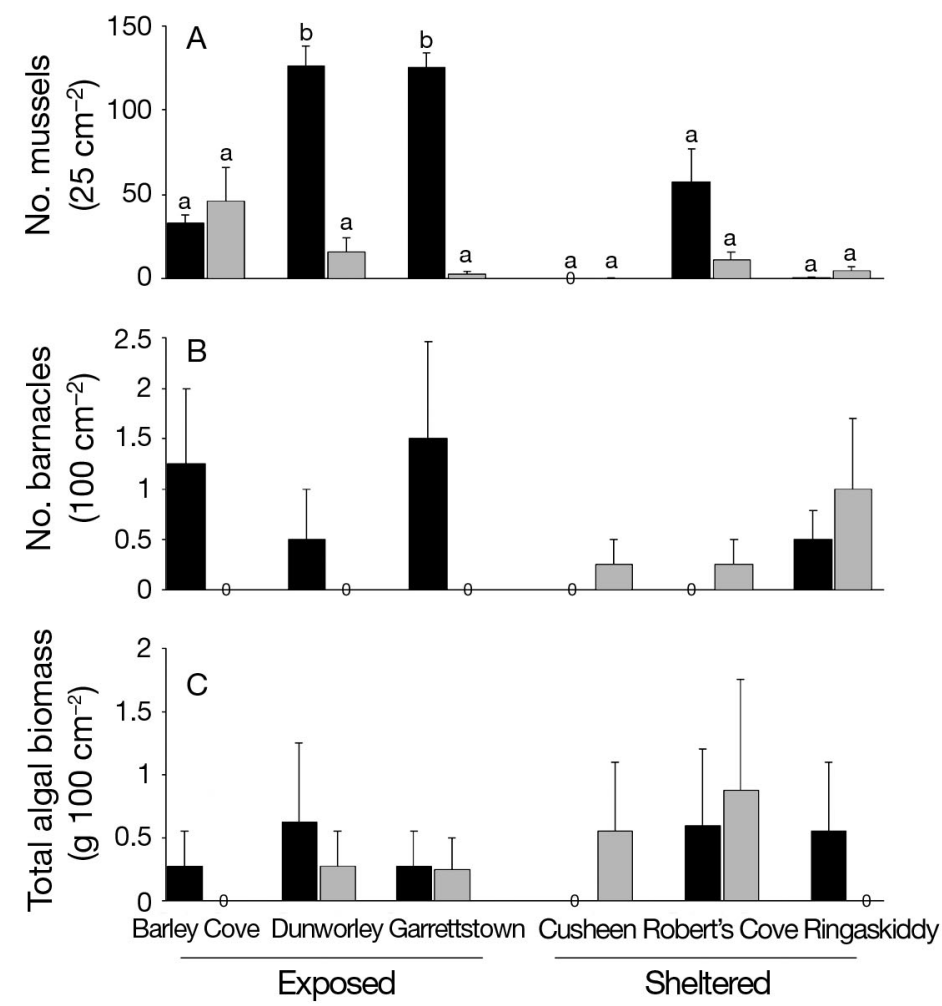

Fig. 2. Mean $(+\mathrm{SE}, \mathrm{n}=4)(\mathrm{A})$ number of mussels on collection pads, (B) number of barnacles on collection tiles and (C) algal biomass accumulated on collection plates at 3 exposed and 3 sheltered shores. Black bars correspond to Time 1 (March to August 2006) and grey bars to Time 2 (September 2006 to February 2007). Zero values are indicated on the $x$ axis where appropriate. Where post hoc tests were conclusive, letters $(a, b, c)$ indicate groups of means that are indistinguishable from each other (where letters differ, $\mathrm{p}<0.05$ ). Untransformed data are shown for clarity

other shores and sampling times (Fig. 2A, Table 1). There was significant interaction between the effect of shore exposure and sampling period on the abundance of newly established barnacles (Fig. 2B, Table 1). This was because, at Time 1, the abundance of newly established barnacles (comprising Chthamalus stellatus and C. montagui) was greater on exposed than sheltered shores. In contrast, during Time 2, newly established barnacles (predominately C. montagui) were restricted to sheltered shores (Fig. 2B). Here, post hoc tests were inconclusive, because, despite the significant interaction between shore exposure and sampling period, the means of barnacle abundances at each location were indistinguishable from each other $(p>0.05)$. There was no effect of shore exposure, sampling period, or location on total biomass of newly established algae (Fig. 2C, Table 1). 
Table 1. Permutational ANOVAs of recruitment (and early growth) of mussels (abundance), barnacles (abundance) and algae (biomass) at 3 exposed and 3 sheltered shores. All data were $\log (x+1)$ transformed, $n=4$. Significant values in bold

\begin{tabular}{|c|c|c|c|c|c|c|c|c|c|c|}
\hline \multirow[t]{2}{*}{ Source of variation } & \multirow[t]{2}{*}{ df } & \multicolumn{3}{|c|}{ Mussels (abundance) } & \multicolumn{3}{|c|}{ Barnacles (abundance) } & \multicolumn{3}{|c|}{ Algae (biomass) } \\
\hline & & MS & Pseudo- $F$ & $\mathrm{p}($ perm $)$ & MS & Pseudo- $F$ & $\mathrm{p}($ perm $)$ & MS & Pseudo- $F$ & $\mathrm{p}($ perm $)$ \\
\hline Time & 1 & 17.83 & 2.73 & 0.17 & 0.37 & 7.78 & 0.06 & 2.17 & 0.23 & 0.66 \\
\hline Exposure & 1 & 46.92 & 2.52 & 0.20 & 4.32 & 5.44 & 1.00 & 1.62 & 0.86 & 0.54 \\
\hline Location (Exposure) & 4 & 9.58 & 1.47 & 0.36 & 0.21 & 4.37 & 0.10 & 7.56 & 0.80 & 0.58 \\
\hline Time $\times$ Exposure & 1 & 11.59 & 1.77 & 0.25 & 1.46 & 30.7 & 0.01 & 5.21 & 0.55 & 0.49 \\
\hline Time $\times$ Location (Exposure) & 4 & 6.5 & 9.3 & $<0.01$ & 4.75 & 0.26 & 0.91 & 9.40 & 0.44 & 0.78 \\
\hline Residual & 36 & 0.7 & & & 0.19 & & & 0.21 & & \\
\hline
\end{tabular}

\section{Effects of consumers and shore exposure on benthic species establishment}

The presence of consumers had a negative effect on the abundance of recently recruited mussels on all shores, and there was no effect of shore exposure on mussels (Fig 3A, Table 2). There was a significant difference in mussel abundance among locations. Post hoc tests show that, first, mussel abundance was greater in treatments that had consumers removed (full cages) compared to the treatments that consumers had access to (no cages) and the control areas (partial cages) on all shores (Fig. 3A). Second, total mussel abundance (of all treatments combined) was lower at Cusheen than on the 3 other shores (Fig. 3A). It is clear that mussel establishment was not greater on exposed shores, as expected, because the abundance of newly established mussels in plots with full cages on exposed and sheltered shores did not consistently differ significantly (Fig. 3A). The effect of consumers on mussel establishment was not greater on sheltered shores, because plots without cages on exposed and sheltered shores also contained similar numbers of newly established small mussels.

No barnacle establishment was recorded on exposed shores during this experiment (Fig. 3B). Although settlement was not measured, all shores were observed regularly during the experiment, and it appears, based on visual assessment, that no macroscopic barnacle recruitment occurred on exposed shores during the experiment. It was not, therefore, possible to test for the effects of consumers on barnacle establishment on exposed shores. On sheltered shores, the presence of consumers had a strong negative effect on the abundance of newly established barnacles (Fig. 3B, Table 2). The significant interaction between location and treatment and the results of subsequent post hoc tests show that when consumers were present, newly-established barnacle abundance differed between the 2 sheltered shores, whereas when consumers were removed, similar abundances of barnacles were established on both shores (Fig. 3B, Table 2). The majority of barnacles $(>90 \%$ ) recorded were Chtha-
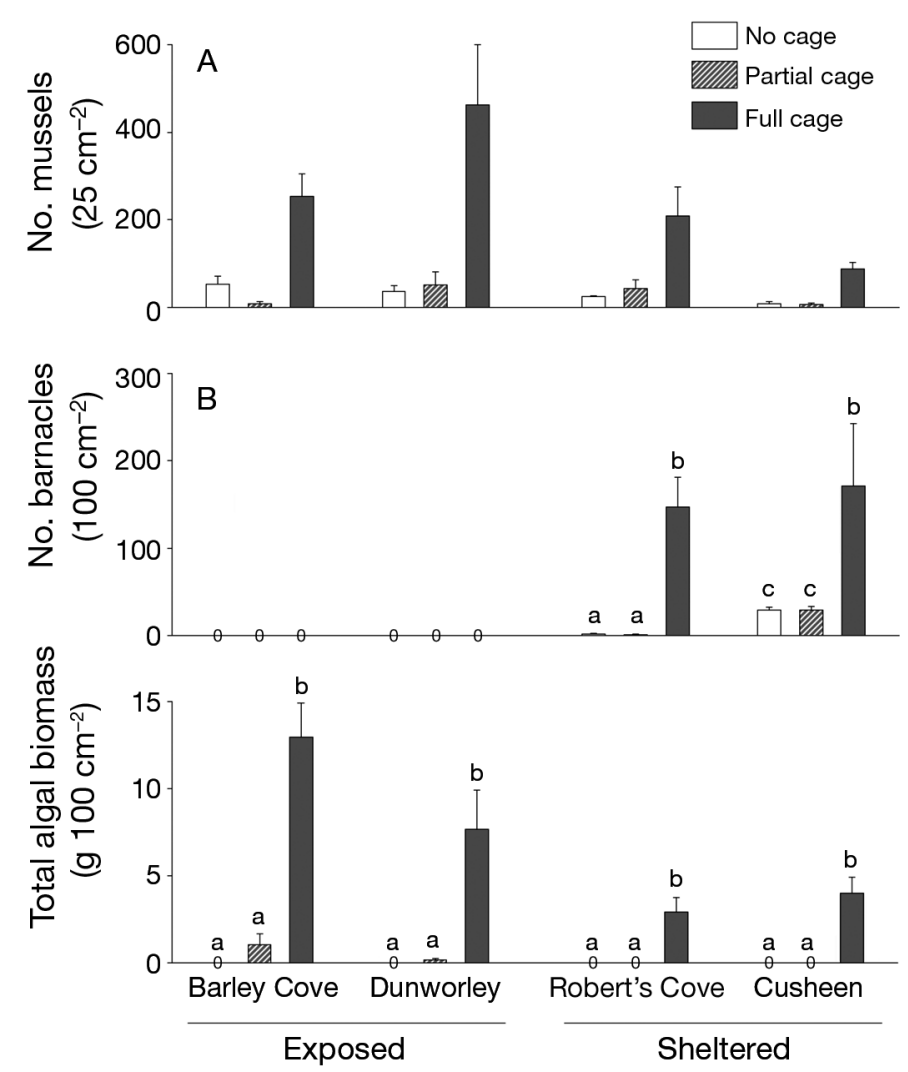

Fig. 3. Mean (+SE, $\mathrm{n}=4)(\mathrm{A})$ number of mussels on collection pads, (B) number of barnacles on collection tiles and (C) algal biomass accumulated on collection plates under each experimental treatment from February to September 2007 at 2 exposed and 2 sheltered shores. Zero values are indicated on the $x$-axis where appropriate. Letters $(a, b, c)$ indicate groups of means that are indistinguishable from each other (where letters differ, $p<0.05$ ). Untransformed data are shown for clarity 
Table 2. ANOVAs of recruitment (and early growth) of mussels (abundance), barnacles (abundance) and algae (biomass) at 2 exposed and 2 sheltered shores, testing the effects of the presence of consumers (treatment). Mussel data were square-root transformed, barnacle and algae data were $\log (x+1)$ transformed, $n=4$. Significant values are shown in bold

\begin{tabular}{|c|c|c|c|c|c|c|c|c|c|c|}
\hline \multirow[t]{2}{*}{ Source of variation } & \multirow[t]{2}{*}{ df } & \multicolumn{3}{|c|}{ Mussels (abundance) } & \multicolumn{3}{|c|}{ Barnacles (abundance) } & \multicolumn{3}{|c|}{ Algae (biomass) } \\
\hline & & MS & $F$ & $\mathrm{p}$ & MS & $F$ & $\mathrm{p}$ & MS & $F$ & $\mathrm{p}$ \\
\hline Exposure & 1 & 102.30 & 2.09 & 0.29 & 106.41 & 10.54 & 0.08 & 1.98 & 5.14 & 0.15 \\
\hline Location (Exposure) & 2 & 49.00 & 3.92 & 0.03 & 10.10 & 64.71 & $<0.01$ & 0.38 & 3.12 & 0.06 \\
\hline Treatment & 2 & 555.51 & 46.60 & $<0.01$ & 11.53 & 4.52 & 0.09 & 16.91 & 140.02 & $<0.01$ \\
\hline Exposure $\times$ Treatment & 2 & 53.03 & 4.45 & 0.10 & 11.53 & 4.52 & 0.09 & 0.77 & 6.35 & 0.06 \\
\hline Treatment $\times$ Location (Exposure) & 4 & 11.92 & 0.95 & 0.44 & 2.55 & 16.35 & $<0.01$ & 0.12 & 0.98 & 0.43 \\
\hline Residual & 36 & 12.49 & & & 0.16 & & & 0.12 & & \\
\hline
\end{tabular}

malus montagui, with a small number of Elminius modestus (an invasive species in Europe), were also present.

The presence of consumers affected total biomass of newly established algae on all shores, and there was no effect of shore exposure on algae (Fig. 3C, Table 2). Although other factors were close to being significant, the conservative constraints of our analyses ( $\alpha=0.01$, see 'Materials and methods'), do not permit interpretation of these factors. Algal assemblages that recruited and grew during the experiment were dominated ( $>95 \%$ of total algal biomass on all shores) by Fucus spp., most of which could not be identified accurately to species at such a young stage. Only 2 experimental plots contained ephemeral algae, and these were 'full cage' treatments at Dunworley (Ulva spp. 0.7 g, Porphyra spp. $0.7 \mathrm{~g}$ ) and Cusheen (Ulva spp. $2.0 \mathrm{~g}$ ).

The abundance of mussels and barnacles and the biomass of algae did not differ significantly between the partial-cage and no-cage treatments on any of the shores (Fig. 3, Table 2), indicating that the presence of the cage did not affect the establishment of any of the target species in the present study.

\section{DISCUSSION}

Our findings demonstrate that consumers play an important role in regulating the establishment of benthic species, regardless of shore exposure to wave action across extremes of wave exposure on rocky shores typical of NW Atlantic regimes. Our first experiment found that mussel establishment was not affected by exposure, but varied among shores during 1 sampling period. Here barnacle establishment varied between sampling periods, showing opposite trends in establishment patterns on exposed and sheltered shores (i.e. barnacle establishment was greater on exposed shores during the first sampling period and greater on the sheltered shores during the second period). These results have to be interpreted with caution, however, because the total abundance of barnacles recruited (mean \pm SD: $0.5 \pm 1$ recruits $100 \mathrm{~cm}^{-2}$ ) was much lower than expected. For example, Delany et al. (2003) recorded mean densities $( \pm \mathrm{SD})$ of Chthamalus motagui to be $66.4 \pm 55.2$ recruits $100 \mathrm{~cm}^{-2}$ and of C. stellatus to be $95.2 \pm 80.0$ recruits $100 \mathrm{~cm}^{-2}$, over a similar period of time on similar shores nearby. The removal of consumers led to an increase in mussel establishment, which again varied among locations but was not affected by shore exposure. Although no barnacle recruitment occurred on the exposed shores during the consumerremoval experiment, it is clear that consumers affected barnacle establishment on the sheltered shores, which also varied spatially (between the sheltered shores). The removal of consumers also led to a substantial increase in algal establishment on all shores where again there was no effect of shore exposure or differences in algal biomass on any of the shores during either experiment.

Our study shows clearly that mussel establishment in southwest Ireland is highly variable, both in time and space, and that shore exposure is not a useful factor in predicting mussel establishment. We did not measure mussel recruitment per se; however, several studies have found greater mussel recruitment on exposed compared with sheltered shores (e.g. Menge 1992, Hunt \& Scheibling 1996, McQuaid \& Lindsay 2005, Pfaff et al. 2011, but see also Petraitis 1991). Our design differed from some previous studies by avoiding to compare pairs of sites (exposed and sheltered) within locations, instead we opted to identify several sites that were representative of exposed and sheltered shores within a region and then selected randomly a subset of these sites to test our hypotheses against a background of natural variation. Any differences among locations were inherent in the design, but other factors relating to spatial variation were not 
explicitly tested. Also, many previous studies were done in upwelling regions, and it is important to consider that variation in recruitment can be driven by many factors at different scales (Schiel 2004). We compared shores that were $10 \mathrm{~s}$ to 100 s of kilometres apart, making it difficult to separate large- and smallscale processes. However, variation in mussel establishment is most likely owing to variability in on-shore recruitment resulting from local-scale processes (Rilov et al. 2008). It is worth noting that larval supply in this region is extremely patchy compared to the relatively deterministic supply of larvae on western Atlantic shores (Jenkins et al. 2008a) or the predictable recruitment patterns of benthic species on the Pacific coast of the Americas, where settlement is often greatest in the lee of headlands (Wing et al. 1995, Connolly et al. 2001) and strongly related to nutrient upwellings (Nielsen \& Navarrete 2004, Navarrete et al. 2005). The shallow-water shelf systems of the Atlantic coasts of Europe are very different from such boundary current/upwelling systems and appear to be much less stable than Atlantic coasts of North America (Jenkins et al. 2008a).

The barnacles Chthamalus stellatus and C. montagui were expected to recruit on all shores during the study (Delany et al. 2003, Power et al. 2006; but see Jenkins 2005). The results of the consumerremoval experiment suggest, however, that the lack of barnacle recruitment on exposed shores is likely to be a function of the availability or behaviour of settling larvae and not due to predation or grazing (Dayton 1971, Hawkins 1983). Experimental plots were monitored closely during the experiment, and no evidence of barnacle settlement was noted on exposed shores. Moreover, great care was taken to remove small predators that could access the cages as soon as they were observed. While other predators such as nemerteans may be present at very low densities, they are not thought to have strong effects on barnacle populations (although this remains to be tested). The lack of barnacle recruitment on exposed shores is not likely to have been an artefact of the collection plates, because no barnacle recruitment was observed on surrounding rock and barnacles recruited onto similar plates on the sheltered shores. Although the spatial and temporal variability of barnacle recruitment has been well studied in western Europe (e.g. Barnes 1956, Benedetti-Cecchi et al. 2000, Jenkins et al. 2001a, Power et al. 2006), there remains an element of unexplained temporal stochasticity (Jenkins et al. 2008b, Burrows et al. 2009).

Another study found that removal of grazers had no effect on barnacle Semibalanus balanoides recruitment and concluded that their experimental cages had protected barnacle recruits from other factors, such as desiccation and algal whiplash (Hancock \& Petraitis 2001). Our experimental plots did not contain macroalgal stands, so it is not likely that larval settlement was impeded by the sweeping action of fucoid algae, as described in other studies (Hawkins 1983, Jenkins \& Hawkins 2003). Further, the partial cages in our study contained similar abundances of barnacles as the treatments without cages, indicating that the presence of cages did not affect barnacle establishment.

Our findings are consistent with those of another study comparing the effects of grazing on seaward and landward sides of artificial breakwaters (Jonsson et al. 2006). It was shown that grazing limited Fucus spp. establishment, while exposure to wave action affected the persistence of individuals once established (Jonsson et al. 2006). It has been suggested that an increase in probability of algal escape from grazing with increasing latitude may drive the increasing dominance of macroalgae in northern Europe, with fucoids extending further into waveexposed shores in northern regions (Jenkins et al. 2005, Coleman et al. 2006). Studies testing how fucoid establishment patterns vary with environmental conditions are, therefore, increasingly important because of regional climate change forecasts for warmer, wetter and windier weather patterns and predictions that fucoids will become increasingly restricted to more sheltered locations over much of their current northern range in western Europe (Ladah et al. 2003, Jonsson et al. 2006).

Recent studies have shown that the interplay between 2 gradients (consumer pressure and sediment deposition) can determine the direction and intensity of interactions between sessile species on rocky shores (Bulleri et al. 2011). Having shown that consumers play an important role in regulating mussel, barnacle and algal establishment, future studies should examine the direct interactions among mussels, barnacles and algae under different gradients of consumer pressure and shore exposure to wave action. While the interactive effects of the loss of key species on rocky shores have been shown to vary with environmental context (Crowe et al. 2011) and through time (O'Connor \& Crowe 2005), more research is required to identify the exact conditions that determine the nature of interactions. There are many physical and biological gradients in nature, and future empirical studies should incorporate multiple gradients of such stresses to enable better understanding of species interactions under different 
environmental conditions in order to address issues regarding altered food-web structure under predicted climate change scenarios (Smit et al. 2009, Bulleri et al. 2011).

Acknowledgements. We sincerely thank M. Anderson for her generous assistance with some statistical issues. For assistance with field work we thank J. O'Brien, J. and S. Quin, D. and D. Sexton. Thanks to A. M. Power for information on barnacle distribution patterns. We are also grateful to L. Benedetti-Cecchi, G. Martins and 3 anonymous reviewers for helpful comments that enhanced this paper. This research was funded by an Irish Research Council for Science, Engineering and Technology (IRCSET) postdoctoral fellowship to N.E.O'C.

\section{LITERATURE CITED}

Anderson MJ (2001) Permutation tests for univariate or multivariate analysis of variance and regression. Can J Fish Aquat Sci 58:626-639

Anderson MJ, Underwood AJ (1997) Effects of gastropod grazers on recruitment and succession of an estuarine assemblage: a multivariate and univariate approach. Oecologia 109:442-453

Anderson MJ, Gorley RN, Clake KR (2008) PERMANOVA+ for PRIMER: guide to software and statistical methods. PRIMER-E, Plymouth

> Barnes H (1956) Balanus balanoides (L.) in the Firth of Clyde: the development and annual variation in the larval population and the causative factors. J Anim Ecol 25: 72-84

> Benedetti-Cecchi L (2000) Predicting direct and indirect interactions during succession in a mid-littoral rocky shore assemblage. Ecol Monogr 70:45-72

Benedetti-Cecchi L, Acunto S, Bulleri F, Cinelli F (2000) Population ecology of the barnacle Chthamalus stellatus in the northwest Mediterranean. Mar Ecol Prog Ser 198: $157-170$

Benedetti-Cecchi L, Bulleri F, Acunto S, Cinelli F (2001) Scales of variation in the effects of limpets on rocky shores in the northwest Mediterranean. Mar Ecol Prog Ser 209:131-141

Bruno JF, Stachowicz JJ, Bertness MD (2003) Inclusion of facilitation into ecological theory. Trends Ecol Evol 18: 119-125

Bulleri F, Cristaudo C, Alestra T, Benedetti-Cecchi L (2011) Crossing gradients of consumer pressure and physical stress on shallow rocky reefs: a test of the stress-gradient hypothesis. J Ecol 99:335-344

Burrows MT, Harvey R, Robb L (2008) Wave exposure indices from digital coastlines and the prediction of rocky shore community structure. Mar Ecol Prog Ser 353:1-12

Burrows MT, Harvey R, Robb L, Poloczanska ES and others (2009) Spatial scales of variance in abundance of intertidal species: effects of region, dispersal mode, and trophic level. Ecology 90:1242-1254

> Coghlan B, Gosling E (2007) Genetic structure of hybrid mussel populations in the west of Ireland: two hypotheses revisited. Mar Biol 150:841-852

Coleman RA, Underwood AJ, Benedetti-Cecchi L, Aberg P and others (2006) A continental scale evaluation of the role of limpet grazing on rocky shores. Oecologia 147: $556-564$

Connell JH (1975) Some mechanisms producing structure in natural communities: a model and evidence from field experiments. In: Cody ML, Diamond JM (eds) Ecology and evolution of Community. Belknap Press, Cambridge, MA, p 460- 490

Connell JH (1985) The consequences of variation in initial settlement vs. post-settlement mortality in rocky intertidal communities. J Exp Mar Biol Ecol 93:11-45

Connolly SR, Menge BA, Roughgarden J (2001) A latitudinal gradient in recruitment of intertidal invertebrates in the northeast Pacific Ocean. Ecology 82:1799-1813

> Crowe TP, Frost NJ, Hawkins SJ (2011) Interactive effects of losing key grazers and ecosystem engineers vary with environmental context. Mar Ecol Prog Ser 430:223-234

> Daleo P, Iribarne O (2009) Beyond competition: the stressgradient hypothesis tested in plant-herbivore interactions. Ecology 90:2368-2374

> Dayton PK (1971) Competition, disturbance and community organisation: the provision and subsequent utilisation of space in a rocky intertidal community. Ecol Monogr 41: 351-389

Delany J, Myers AA, McGrath D, O'Riordan RM, Power AM (2003) Role of post-settlement mortality and 'supply-side' ecology in setting patterns of intertidal distribution in the chthamalid barnacles Chthamalus montagui and C. stellatus. Mar Ecol Prog Ser 249:207-214

Denley EJ, Underwood AJ (1979) Experiments on factors influencing settlement, survival and growth of two species of barnacles in New South Wales. J Exp Mar Biol Ecol 36:269-293

> Fairweather PG, Underwood AJ (1991) Experimental removals of a rocky intertidal predator: variations within two habitats in the effects on prey. J Exp Mar Biol Ecol 154:29-75

Farrell TM (1991) Models and mechanisms of succession: an example from a rocky intertidal community. Ecol Monogr 61:95-113

Hancock KM, Petraitis PS (2001) Effects of herbivorous snails and macroalgal canopy on recruitment and early survivorship of the barnacle Semibalanus balanoides. J Exp Mar Biol Ecol 257:205-218

Hawkins SJ (1981) The influence of season and barnacles on the algal colonization of Patelle vulgata exclusion areas. J Mar Biol Assoc UK 61:1-15

Hawkins SJ (1983) Interactions of Patella and macroalgae with settling Semibalanus balanoides (L.). J Exp Mar Biol Ecol 71:55-72

Hawkins SJ, Hartnoll RG (1983) Grazing of intertidal algae by marine invertebrates. Oceanogr Mar Biol Annu Rev 21:195-282

Hawkins SJ, Hartnoll RG, Kain JM, Norton TA (1992) Plant-animal interactions on hard substrata in the northeast Atlantic. In: John DM, Hawkins SJ, Price JH (eds) Plant-animal interactions in the marine benthos. Clarendon Press, Oxford, p 1-32

> Hunt HL, Scheibling RE (1996) Physical and biological factors influencing mussel (Mytilus trossulus, $M$. edulis) settlement on a wave-exposed rocky shore. Mar Ecol Prog Ser 142:135-145

Jenkins SR (2005) Larval habitat selection, not larval supply, determines settlement patterns and adult distribution in two chthamalid barnacles. J Anim Ecol 74:893-904

Jenkins SR, Hawkins SJ (2003) Barnacle larval supply to 
sheltered rocky shores: A limiting factor? Hydrobiologia 503:143-151

- Jenkins SR, Hawkins SJ, Norton TA (1999) Direct and indirect effects of a macroalgal canopy and limpet grazing in structuring a sheltered inter-tidal community. Mar Ecol Prog Ser 188:81-92

> Jenkins SR, Aberg P, Cervin G, Coleman RA and others (2001a) Population dynamics of the intertidal barnacle Semibalanus balanoides at three European locations: spatial scales of variability. Mar Ecol Prog Ser 217: 207-217

> Jenkins SR, Arenas F, Arrontes J, Bussell J and others (2001b) European-scale analysis of seasonal variability in limpet grazing activity and microalgal abundance. Mar Ecol Prog Ser 211:193-203

- Jenkins SR, Coleman RA, Della Santina P, Hawkins SJ, Burrows MT, Hartnoll RG (2005) Regional scale differences in the determinism of grazing effects in the rocky intertidal. Mar Ecol Prog Ser 287:77-86

> Jenkins SR, Moore P, Burrows MT, Garbary DJ and others (2008a) Comparative ecology of North Atlantic shores: Do differences in players matter for process? Ecology 89: S3-S23

> Jenkins SR, Murua J, Burrows MT (2008b) Temporal changes in the strength of density-dependent mortality and growth in intertidal barnacles. J Anim Ecol 77 : 573-584

Jernakoff P (1985) The effect of overgrowth by algae on the survival of the intertidal barnacle Tesseropora rosea (Krauss). J Exp Mar Biol Ecol 94:89-98

> Jonsson PR, Granhag L, Moschella PS, Aberg P, Hawkins SJ, Thompson RC (2006) Interactions between wave action and grazing control the distribution of intertidal macroalgae. Ecology 87:1169-1178

King PA, McGrath D, Gosling EM (1989) Reproduction and settlement of Mytilus edulis on an exposed rocky shore in Galway Bay, west coast of Ireland. J Mar Biol Assoc UK 69:355-365

King PA, McGrath D, Britton W (1990) The use of artificial substrates in monitoring mussel (Mytilus edulis) settlement on an exposed rocky shore in the west of Ireland. J Mar Biol Assoc U K 70:371-380

Ladah L, Bermudez R, Pearson G, Serrao E (2003) Fertilization success and recruitment of dioecious and hermaphroditic fucoid seaweeds with contrasting distributions near their southern limit. Mar Ecol Prog Ser 262:173-183

Lubchenco J (1983) Littorina and Fucus: effects of herbivores, substratum heterogeneity, and plant escapes during succession. Ecology 64:1116-1123

Maron JL, Crone E (2006) Herbivory: effects on plant abundance, distribution and population growth. Proc R Soc Lond B 273:2575-2584

> McArdle BH, Anderson MJ (2001) Fitting multivariate models to community data: a comment on distance-based redundancy analysis. Ecology 82:290-297

> McQuaid CD, Lindsay JR (2005) Interacting effects of wave exposure, tidal height and substratum on spatial variation in densities of mussel Perna perna plantigrades. Mar Ecol Prog Ser 301:173-184

> Menge BA (1992) Community regulation: Under what conditions are bottom-up factors important on rocky shores? Ecology 73:755-765

> Menge BA (2000) Top-down and bottom-up community regulation in marine habitats. J Exp Mar Biol Ecol 250: 257-289
Menge BA, Branch GM (2001) Rocky intertidal communities. In: Bertness MD, Gaines SD, Hay ME (eds) Marine community ecology. Sinuaer Associates, Sunderland, MA, p 221-251

Menge BA, Olson AM (1990) Role of scale and environmental factors in regulation of community structure. Trends Ecol Evol 5:52-57

Menge BA, Sutherland JP (1976) Species diversity gradients: synthesis of roles of predation, competition and temporal heterogeneity. Am Nat 110:351-369

Menge BA, Sutherland JP (1987) Community regulation: variation in disturbance, competition, and predation in relation to environmental-stress and recruitment. Am Nat 130:730-757

> Menge BA, Berlow EL, Blanchette CA, Navarette SA, Yamada SB (1994) The keystone species concept: variation in interaction strength in a rocky intertidal habitat. Ecol Monogr 64:249-286

Minchinton TE, Scheibling RE (1993) Variation in sampling and frequency affect estimates of recruitment of barnacles. Mar Ecol Prog Ser 99:83-88

> Navarrete SA, Wieters EA, Broitman BR, Castilla JC (2005) Scales of benthic-pelagic coupling and the intensity of species interactions: from recruitment limitation to topdown control. Proc Natl Acad Sci USA 102:18046-18051

Nielsen KJ, Navarrete SA (2004) Mesoscale regulation comes from the bottom-up: intertidal interactions between consumers and upwelling. Ecol Lett 7:31-41

O'Connor NE (2010) Shore exposure affects mussel population structure and mediates the effect of epibiotic algae on mussel survival in SW Ireland. Estuar Coast Shelf Sci 87:83-91

$>$ O'Connor NE, Crowe TP (2005) Biodiversity loss and ecosystem functioning: distinguishing between number and identity of species. Ecology 86:1783-1796

O'Connor NE, Crowe TP (2008) Do mussel patches provide a refuge for algae from grazing gastropods? J Molluscan Stud 74:75-78

O'Connor NE, Crowe TP, McGrath D (2006) Effects of epibiotic algae on the survival, biomass and recruitment of mussels, Mytilus L. (Bivalvia: Mollusca). J Exp Mar Biol Ecol 328:265-276

> Petraitis PS (1987) Factors organizing rocky intertidal communities of New England: herbivory and predation in sheltered bays. J Exp Mar Biol Ecol 109:117-136

Petraitis PS (1990) Direct and indirect effects of predation, herbivory and surface rugosity on mussel recruitment. Oecologia 83:405-413

Petraitis PS (1991) Recuitment of the mussel Mytilus edulis on sheltered and exposed rocky shores in Maine, USA. J Exp Mar Biol Ecol 147:65-80

Pfaff MC, Branch GM, Wieters EA, Branch RA, Broitman BR (2011) Upwelling intensity and wave exposure determine recruitment of intertidal mussels and barnacles in the southern Benguela upwelling region. Mar Ecol Prog Ser 425:141-152

Power AM, Delany J, McGrath D, Myers AA, O'Riordan RM (2006) Patterns of adult abundance in Chthamalus stellatus (Poli) and C. montagui Southward (Crustacea: Cirripedia) emerge during late recruitment. J Exp Mar Biol Ecol 332:151-165

Quinn GP, Keough MJ (2002) Experimental design and data analysis for biologists. Cambridge University Press, Cambridge

> Rilov G, Schiel DR (2006) Seascape-dependent subtidal- 
intertidal trophic linkages. Ecology 87:731-744

Rilov G, Dudas SE, Menge BA, Grantham BA, Lubchenco J, Schiel DR (2008) The surf zone: A semi-permeable barrier to onshore recruitment of invertebrate larvae? J Exp Mar Biol Ecol 361:59-74

Sams MA, Keough MJ (2007) Predation during early postsettlement varies in importance for shaping marine sessile communities. Mar Ecol Prog Ser 348:85-101

Schiel DR (2004) The structure and replenishment of rocky shore intertidal communities and biogeographic comparisons. J Exp Mar Biol Ecol 300:309-342

Smit C, Rietkerk M, Wassen MJ (2009) Inclusion of biotic stress (consumer pressure) alters predictions from the stress gradient hypothesis. J Ecol 97:1215-1219

Sousa WP, Connell JH (1992) Grazing and succession in marine algae. In: John DM, Hawkins SJ, Price JH (eds) Plant-animal interactions in the marine benthos. Oxford University Press, Oxford, p 425-441

Southward AJ (1964) Limpet grazing and the control of vegetation on rocky shores. In: Crisp DJ (ed) Grazing in terrestrial and marine environments. Blackwell Scientific, Oxford

Taylor DI, Schiel DR (2010) Algal populations controlled by fish herbivory across a wave exposure gradient on southern temperate shores. Ecology 91:201-211

Thompson RC, Norton TA, Hawkins SJ (2004) Physical stress and biological control regulate the producer-consumer balance in intertidal biofilms. Ecology 85: 1372-1382

Underwood AJ (1980) The effects of grazing by gastropods and physical factors on the upper limits of distribution of

Editorial responsibility: Lisandro Benedetti-Cecchi, Pisa, Italy intertidal macroalgae. Oecologia 46:201-213

> Underwood AJ (1981) Structure of a rocky intertidal community in New South Wales: patterns of vertical distribution and seasonal changes. J Exp Mar Biol Ecol 51:57-85

Underwood AJ (1997) Experiments in ecology: their logical design and interpretation using analysis of variance. Cambridge University Press, Cambridge

- Underwood AJ, Jernakoff P (1981) Effects of interactions between algae and grazing gastropods on the structure of a low shore intertidal algal community. Oecologia 48: 221-233

> Underwood AJ, Jernakoff P (1984) The effects of tidal height, wave-exposure, seasonality and rock-pools on grazing and the distribution of intertidal macroalgae in New South Wales. J Exp Mar Biol Ecol 75:71-96

Underwood AJ, Petraitis PS (1993) Structure of intertidal assemblages in different locations: How can local processes be compared? In: Ricklefs RE, Schluter D (eds) Species diversity in ecological communities: historical and geographical perspectives. University of Chicago Press, Chicago, IL, p 39-51

- Underwood AJ, Denley EJ, Moran MJ (1983) Experimental analyses of the structure and dynamics of mid-shore rocky intertidal communities in New South Wales. Oecologia 56:202-219

Watson DI, Barnes DKA (2004) Temporal and spatial components of variability in benthic recruitment, a 5-year temperate example. Mar Biol 145:201-214

Wing SR, Largier JL, Botsford LW, Quinn JF (1995) Settlement and transport of benthic invertebrates in an intermittent upwelling region. Limnol Oceanogr 40:316-329

Submitted: December 6, 2010; Accepted: September 20, 2011 Proofs received from author(s): December 13, 2011 